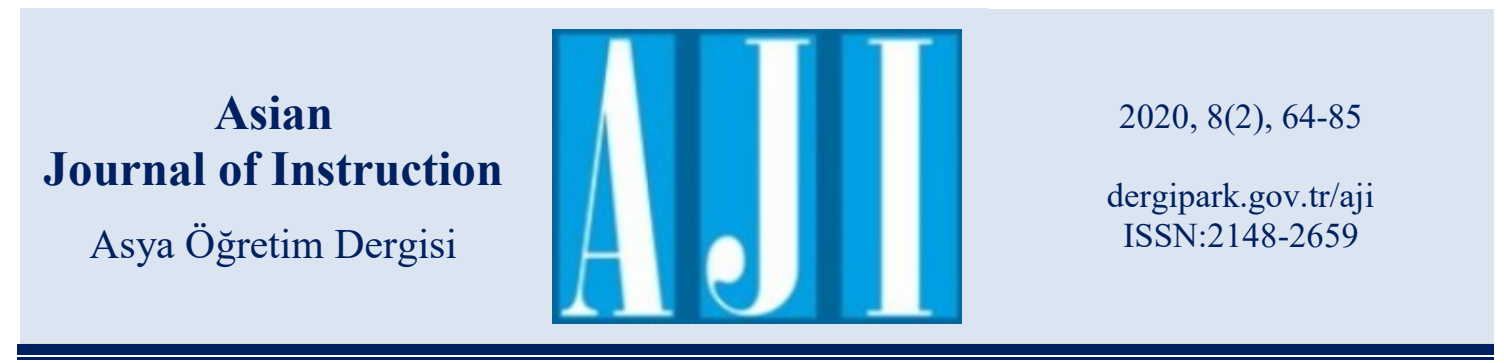

Kabul Tarihi: 23/12/2020

Yayınlanma Tarihi: 26/12/2020

\title{
Kademelendirilmiş Etkinlik Yoluyla Metin Tabanlı Programlama Öğretimi: İşbirlikli Bir Eylem Araştırması
}

\author{
Erkan Geçitli ${ }^{1}$, Nilay Bumen ${ }^{2}$
}

Geçitli, E., \& Bumen, N. (2020). Kademelendirilmiş etkinlik yoluyla metin tabanlı programlama öğretimi: İşbirlikli bir eylem araştırmas1. Asya Ö̆gretim Dergisi, 8(2), 64-85. https://doi.org/10.47215/aji.791967

\section{$\ddot{\mathbf{O} z}$}

$\mathrm{Bu}$ çalışmada, farklılaştırılmış öğretim tekniklerinden kademelendirilmiş etkinlik temele alınarak hazırlanmış bir eylem planının dokuzuncu sınıf seçmeli Bilgisayar Bilimi dersinde öğrencilerin programlamaya yönelik tutumlarına, güdülenme düzeylerine ve program yazma becerilerine nasıl katk1 sağladığı incelenmektedir. İşbirlikli eylem araştırması türünde olan çalışma, karma yöntem desenlerinden yakınsak desen ile yürütülmüş, Manisa'daki bir Anadolu Lisesi'nde öğrenim gören 30 öğrenci ile gerçekleştirilmiştir. Araştırmacılar tarafindan hazırlanan eylem planı sekiz hafta boyunca uygulanmış, veri toplamada "Öğrencilerin Programlamaya Yönelik Tutumunun Belirlenmesi Ölçeği”, “Akademik Güdülenme Ölçeği”, ders video kayıtları, görüşmeler, elektronik ürün değerlendirmeleri ve öğrenci günlükleri kullanılmıştır. Bu araçlar aracılı̆̆ıyla toplanan nicel veriler üzerinde t-testi, ANOVA ve Wilcoxon işaretli sıralar testi, nitel veriler üzerinde ise içerik analizi yapılmıştır. Nicel ve nitel bulgular birleştirildiğginde, uygulanan eylem planının öğrencilerin programlamaya yönelik tutumlarında olumlu bir değişiklik oluşturabildiği görülmektedir. Başlangıç ve ileri seviyedeki grupların hazırladıkları elektronik ürünlerin (yazılımların) daha yüksek puan aldığı görülmüş, orta ve ileri seviyedeki grupların tasarladığı elektronik ürünlerin aldığı puanlar arasında da anlamlı farka rastlanmıştır. Nicel bulgular öğrencilerin akademik güdülenme düzeylerinde istatistiksel olarak anlamlı bir fark göstermese de, nitel bulgular verilen görevden fazlasını yapmak istediklerini ve birçok grubun görevlerini gerçekleştirmek için teneffüslerde bile sınıfta kalmayı tercih ettiğini göstermektedir. Bu sonuçlar farklılaştırılmış öğretim tekniklerinden biri olan kademelendirilmiş etkinlik yoluyla programlama öğretiminin, lise öğrencilerin programlamaya yönelik tutumlarına, güdülenme düzeylerine ve program yazma becerilerine olumlu katkıları olduğunu göstermektedir.

Anahtar Kelimeler: Bilgi işlemsel düşünme, bilgisayar bilimi dersi, farklılaştırılmış öğretim, kademelendirilmiş etkinlik, programlama öğretimi

\section{Text-Based Programming Instruction Through Tiered Activity: A Collaborative Action Research}

\begin{abstract}
This study examines how an action research on tiered activities from differentiated instructional techniques contributes to $9^{\text {th }}$ graders' attitudes towards programming, motivation levels and programming skills in the elective Computer Science course. The study adopting cooperative action research was conducted through the convergent design from the mixed methods. An eight-week action plan developed by the researchers was carried out with 30 students from an Anatolian High School in Manisa. "Attitude Scale Towards Computer Programming", "Academic
\end{abstract}

\footnotetext{
1 Öğretmen, Milli Eğitim Bakanlığı, ORCID: 0000-0001-7700-8690, erkangecitli01@gmail.com

${ }^{2}$ Prof. Dr., Ege Üniversitesi, ORCID: 0000-0003-1891-6589, nilay.bumen@ege.edu.tr
} 
Motivation Scale", video recordings of the courses, interviews, tiered software rubrics, and student diaries were utilized to collect the data. For the analysis of the data collected through these tools, t-test, ANOVA and Wilcoxon signed ranks test were performed on the quantitative data, and a content analysis was used on the qualitative data. With the combination of quantitative and qualitative findings, the study indicates that the action plan implemented at $9^{\text {th }}$ grade can make a positive change in the students' attitudes towards programming. It was found out that the electronic products (softwares) developed by the beginner and advanced groups got higher scores. Also, a significant difference between the intermediate and advance groups' scores from the softwares was found. Although the quantitative findings do not indicate a statistically significant difference in the students' academic motivation levels, the qualitative findings revealed that the students showed a willingness to do more than the task given, and many groups preferred to stay in class to perform the task even at recess. These results implied that programming instructions through tiered activities from the differentiated teaching techniques might have contributions to the students' attitudes towards programming, motivation levels and programming skills.

Keywords: Computational thinking, computer science course, differentiate instruction, teaching programming, tiered instruction

\section{Giriş}

Günümüzde, geleneksel okuduğunu anlama ve temel matematik becerilerinin ötesinde öğrencilerin kazanması gereken yeni beceriler tanımlanmaktadır. Bu becerilerden biri olan bilgi işlemsel düşünme becerisi, Wing tarafindan 2006 yılında ortaya atılmıştır. Wing (2006: 33) bu beceriyi sadece bilgisayar bilimciler için değil, herkes için temel bir beceri olarak tanımlamaktadır. Bilgi işlemsel düşünme becerisi, "problem çözme, sistem tasarlama ve bilgisayar bilimi temel kavramları kullanılarak insan davranışlarının anlaşılmasını içermektedir". Programlama öğretimi bilgi işlemsel düşünme becerisinin gelişimine katk1 sağlayan yollardan biridir (Alsancak Sırakaya, 2019; Numanoğlu \& Keser, 2017). Öğrencilerin bilgi işlemsel düşünme becerisine mantıksal düşünme ve problem çözme becerilerinin de katkısı olduğu bilinmekle birlikte, birçok ülke anaokulundan liseye kadar programlama becerilerine daha çok odaklanmaktadır (Garcia-Penalvo \& Cruz-Benito, 2016).

Programlama öğretiminde yükseköğretim ilk akla gelen düzey olmakla birlikte (Yıldız Durak, 2018), Estonya, Yunanistan, İngiltere ve Avusturalya gibi birçok ülke anaokulundan liseye kadar programlama öğretimini gerçekleştirmektedir (Popat \& Starkey, 2019). Liselerde yürütülen programlama eğitiminde metin tabanlı programlama ve blok tabanlı programlama uygulamalarına bir arada rastlanabilmektedir. Weintrop ve Wilensky (2017) bu uygulamaları karşılaştırmış, blok tabanlı programlama öğretimi öğrencilerin ilgisini daha çok çekse de, metin tabanlı programlama ile çalışan öğrencilerin programlama tecrübelerinin profesyonel programcıların yaptıklarına benzer olduğundan, programlama becerilerini geliştirmede daha etkili olduğunu belirlemişlerdir. Türkiye'de de Milli Eğitim Bakanlığı (MEB) tarafından 2018 yılında yayımlanan Bilgisayar Bilimi dersi öğretim programında, metin tabanlı programlama ögretimi temele alınmaktadır.

Birçok çalışmaya göre, özellikle problem çözme becerileri ve etkili çözüm tasarımı oluşturma yeterliliği olmayan öğrenciler için programlama öğrenmek zordur (Başer, 2013; Bennedsen \& Caspersen, 2019; Erümit vd., 2019; Qian \& Lehman, 2017; Yıldız Durak, 2018). Qian ve Lehman (2017), programlamayı öğrenme sürecindeki zorlanmalarda programlama sözdizimi bilgisi, doğal dil, matematik, yanlış zihinsel modeller, strateji eksikliği, programlama ortamları, öğretmenlerin bilgi ve öğretim becerileri gibi birçok faktörün etkisi olduğunu belirtmektedirler. Erümit ve diğerlerine (2019) göre ise programlama araçlarının ve programlama dillerinin zor bir yapıya sahip olmaları nedeniyle geleneksel öğretim yöntemleriyle programlama öğretiminde zorluklar yaşanabilmektedir. 
Günümüzde eğitimciler aktif öğrenme ortamları oluşturmak için çaba harcamakta ve öğrencileri oluşturdukları bir takım zorluklar yoluyla problem çözmelerini sağlayacak etkinliklere yöneltmektedirler (Sáez-López, Román-González \& Vázquez-Cano, 2016). Fakat bunun yanında ön bilgisi, tutumu, sosyoekonomik yapısı, öğrenme stili, çoklu zeka alanı birbirinden farklı öğrencilere aynı tip öğretim yapmak yerine, mümkün olduğunca öğretimin çeşitlendirilmesi gerekmektedir. Farklılaştırılmış öğretim bu amaçlara hizmet eden yaklaşımlardan biridir (Avcı \& Yüksel, 2018).

Farklılaştırılmış öğretim, öğrencilerin hazırbulunuşluk, ilgi ve öğrenme stilini dikkate alarak kapasitelerinin en üst seviyelerine ulaşmaları için öğretmenlere rehberlik eden bir öğretim modelidir (Tomlinson, 2000). Bu model aynı zamanda öğrenme ve öğretimde esnek, eşitlikçi ve akı1lı bir yaklaşım olarak tanımlanır. Günümüzde okullar ve öğretmenler öğrenci çeşitliliği ile başa çıkma talebinin artmasıyla birlikte farklı gelişimsel ihtiyaçlara ve bireylerin değişen düzeylerine uyum sağlama sorumluluğuna sahiptir (Suprayogi, Valcke \& Godwin, 2017). Öğrencilerin kendi ihtiyaçlarına uygun öğretim etkinlikleri almaları öğretimi etkili k1lar ve bu yaklaşımda öğretimi uyarlamak için öğretmenlerin çaba göstermesinin gerekli olduğu kabul edilir (van Geel vd., 2019). Farklılaştırılmış öğretim, yapısında birçok öğretim tekniğini (merkezler, istasyon, kademelendirilmiş etkinlik, öğrenme sözleşmesi, ajanda, öykü temelli öğrenme, grup araştırması, karmaşı öğretim, program sıkıştırma, okuma çemberi) barındırmaktadır. Bunlardan biri olan kademelendirilmiş etkinlik tekniği, farklı öğrenme seviyeleri olan sinıflarda kullanılmak için oldukça uygundur (Avc1 \& Yüksel, 2018; Salar, 2018).

Kademelendirilmiş etkinlik tekniği temelde ilgi, hazırbulunuşluk ve öğrenme stillerine duyarlıdır. Bu teknikle hazırlanan bir ders, öğretmenin öğrencilerin ilgi ve beceri düzeylerini iyi anladığını ve kademelendirmeyi bu ihtiyaçları karşılayacak şekilde tasarladığını gösterir (Pierce \& Adams, 2004). Bu yolla öğretmen öğrencilerin hazırbulunuşlukları, ilgi alanları veya öğrenme stillerine uygun olarak dersi yeniden düzenleyebilir (Levy, 2008). Ayrıca bu teknikte tüm öğrenci gruplarının ihtiyaçlarını karşılamak üzere hem öğretim iş yükünü hem de öğretim programlarını yönetebilmek gerekmektedir. Öğretimi öğretmen için daha yönetilebilir hale getirmek için farklılaştırılmış düzeylerin veya esnek öğretim gruplarının sayısını sınırlamak mümkündür. Tipik bir karma sınıfta her bir kavram öğretimi için ortalama öğrenci düzeyleri dikkate alınmaktadır. Kademelendirilmiş etkinlikte ise her aşama öğrenenlere karşı duyarlıdır ve farklılaştırılacak içerik, süreç veya ürün eğitim programlarında ele alınırken öğrencinin hazırbulunuşluk düzeyiyle eşleşecek şekilde yapılandırılır (Richards \& Omdal, 2007). Pierce ve Adams (2004), öğretmenlere Kademelendirilmiş etkinliğin uygulanmasında yardımcı olabilecek bazı adımlar önermektedir. Bunlar: a) sınıf seviyesi, konu, hedefler ve temel kavramların belirlenmesi, b) öğrencilerin derste başarılı olabilmeleri için hazırbulunuşluluklarının yeterli olduğundan emin olunması, c) neyin ya da nelerin kademelenedirileceğine karar verilmesi (içerik, süreç, ürün), d) kademelendirme tipine (ilgi, öğrenme stili, hazırbulunuşluk) karar verilmesi, e) ihtiyaç duyulan kademe sayısına karar verilerek dersin geliştirilmesi, f) son olarak ders için gerekli değerlendirme araçlarının geliştirilmesidir. Bu çalışmada hem farklı öğrenme düzeyindeki öğrencilere ulaşabilmek hem de metin tabanlı programlama araçlarının ve programlama öğrenmenin zorluğuna çözüm üretebilmek amacıyla kademelendirlimiş etkinliği temele alan bir eylem planı tasarlanmıştır. Eylem planının tasarlanmasında Pierce ve Adams'ın (2004) önerdiği adımlar dikkate alınmıştır.

Çalışmanın, metin tabanlı programlama ile ilk kez lisede karşılaşan öğrencilere ve bu öğrencilerin programlama öğrenme sürecinde yaşadıkları sorunları çözmeye çalışan eğitimcilere yardımcı olması açısından alanyazına katkı sağlayacağı düşünülmektedir. Metin tabanlı programlama öğretiminin zorlukları (Bennedsen \& Caspersen, 2019; Erümit vd., 2019; Qian \& Lehman, 2017; Yıldız Durak, 2018) düşünüldüğünde, kademelendirilmiş öğretim tekniğiyle bu 
sorunların çözümüne yönelik bir takım fikirlerin oluşması mümkündür. Ayrıca bu çalışmanın diğer farklılaştırılmış öğretim tekniklerinin de programlama öğretiminde denenmesine yol gösterici olması açısından önemli olacağı düşünülmektedir. Liseler için tasarlanan Bilgisayar Bilimi dersi öğretim programlarında farklılaștırılmış öğretim tekniklerinin daha çok yer alması ve bu dersleri yürüten öğretmenlere yönelik mesleki gelişim programlarının yaygınlaştırılması açısından da çalışmanın katkı sunabileceği düşünülmektedir.

Bu bağlamda bu çalışmada, seçmeli Bilgisayar Bilimi dersinde kademelendirilmiş etkinlik tekniği temele alınarak hazırlanmış bir eylem planının öğrencilerin tutumlarına, güdülenme düzeylerine ve program yazma becerilerine nasıl katkı sağladığ 1 incelenmiştir. Çalışmada aşağıdaki sorulara yanıt aranmıştır:

1. Farklılaştırılmış öğretim stratejilerinden kademelendirilmiş etkinlik yoluyla yapılan metin tabanlı programlama öğretimi, öğrencilerin programlamaya yönelik tutum ve akademik güdülenmelerine nasıl katkı sağlamaktadır?

2. Farklılaştırılmış öğretim stratejilerinden kademelendirilmiş etkinlik yoluyla yapılan metin tabanlı programlama öğretimi öğrencilerin metin tabanlı program yazma becerilerine nasıl katkı sağlamaktadır?

3. Öğrencilerin kademelendirilmiş etkinliğe ilişkin görüşleri nelerdir?

\section{Yöntem}

\subsection{Araştırma Modeli}

Çalışma, bir takım araştırması niteliği taşıyan, işbirlikli eylem araştırması türündedir. İşbirlikli eylem araştırmaları; hem üniversite ve okul araştırmacılarının araştırma ortaklığı olarak, hem de bağımsız eylem araştırması yapan bir uygulayıcı ekibi olarak tanımlanmaktadır (Gordon \& Solis, 2018:2). İyi yürütüldüğü takdirde, işbirlikli eylem araştırmalarının bireysel, takım ve okul düzleminde önemli yararları olduğu ve dahası öğrencilerin öğrenmelerini geliştirmeye önderlik edebileceği belirtilmektedir (Adams \& Townsend, 2014).

Çalışmada verilerin toplanması, analizi, bulguların bütünleştirilmesi ve önerilerin oluşturulmasında karma yöntem desenlerinden yakınsak (convergent) desen kullanılmıştır. Bu desen nicel ve nitel bulguları karşılaştırmak veya birleştirmek için bir araya getirilmesi amaçlandığında uygundur (Creswell \& Plano Clark, 2018). Yakınsak desenin nasıl kullanıldığı Şekil 1'de gösterilmektedir:

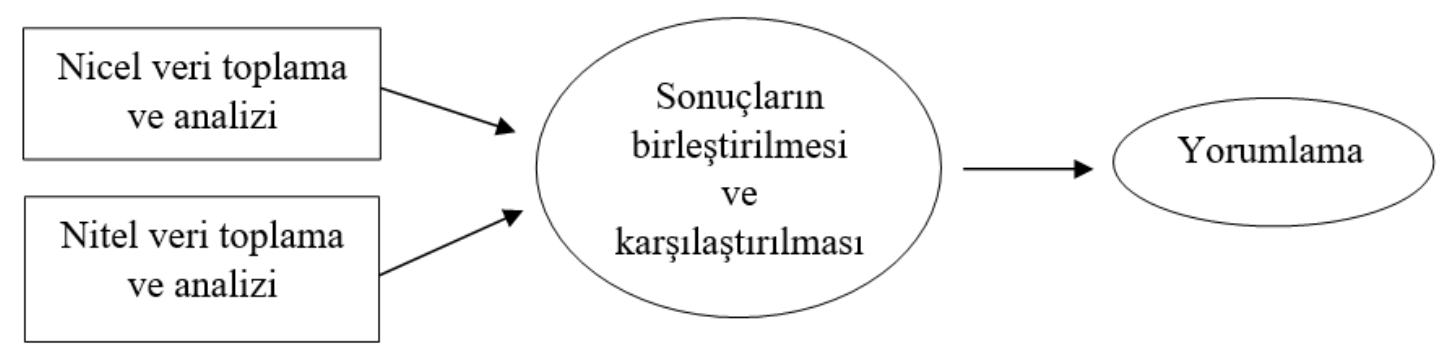

Şekil 1. Yakınsak (Convergent) Desen (Creswell \& Plano Clark, 2018)

\section{2. Çalışma Grubu}


Katılımcıların belirlenmesinde amaçlı örnekleme yöntemlerinden kolay ulaşılabilir örnekleme yöntemi kullanılmış, çalışma 2018-2019 öğretim yılında Manisa'daki bir Anadolu Lisesi'nin 9. sınıfında öğrenim gören 30 öğrenci ile gerçekleştirilmiştir. Görüşmeler ise, öğrenciler tarafından kademelendirilmiş etkinlik için oluşturulan grupların sözcüleri $(n=10)$ ile gerçekleştirilmiştir. Şubede yer alan öğrencilerin 18'i kız, 12'si erkektir. Yaşları 14 ve 15 arasında değişmektedir.

\subsection{Veri Toplama Araçları}

\subsection{1. Öğrencilerin Programlamaya Yönelik Tutumunun Belirlenmesi Ölçeği (ÖPYTBÖ)}

Altay ve Kışla (2018) tarafından lise öğrencilerinin programlamaya yönelik tutumlarını belirlemek amacıyla geliştirilen ölçek, Likert tipinde cevaplanan 14 maddeden oluşmaktadır. Ölçeğin Cronbach Alfa güvenirlik katsayısı .89 , ölçeğin açıkladığı toplam varyans ise \% 65.71'dir. Ölçeğin bu araştırma için kullanımından elde edilen Cronbach Alfa güvenirlik katsayıs1 .92'dir.

\subsubsection{Akademik Güdülenme Ölçeği (AGÖ)}

Bozanoğlu (2004) tarafından lisede öğrenim gören öğrencilerin akademik güdülenme düzeylerini belirlemek amacıyla geliştirilen ölçek 20 maddeden oluşmaktadır. Ölçekten elde edilebilecek en yüksek puan 100 ve en düşük puan 20'dir. Ölçeğin bu araştırma için kullanımından elde edilen Cronbach Alfa güvenirlik katsayısı .90'dır.

\subsubsection{Video Kayttlart}

Yürütülen eylem planının beş haftasında aynı zamanda dersin öğretmeni olan ilk araştırmacının sınıfında derslerin video kaydı (toplam süre 284 dakika 5 saniye) alınmıştır. Kayıtlar sınıfın bir köşesine sabitlenen bir kamera ile elde edilmiştir. İlk kayıttan önce öğrencilere çalışma hakkında kısa bir bilgi verilmiş ve süreçte olumsuz bir tepkiyle karşılaşılmamıştır.

\subsection{4 Öğrenci Görüşme Formu}

Gerçekleştirilen eylem planı sonunda öğrencilerin (grup sözcülerinin) sürece ait görüşlerini almak amacıyla yüz yüze görüşmeler yapılmıştır. Görüşmeler için araştırmacılar tarafindan oluşturulan taslak form Eğitim Programları ve Öğretim alanında çalışan iki öğretim üyesi tarafından incelenmiştir. Öneriler doğrultusunda değişiklikler yapılmış, daha sonra bir öğrenci ile denenmiş, anlaşılamayan ifadeler yeniden düzenlenmiş̧ir. Süreç sonunda 13 maddeden oluşan öğrenci görüşme formu elde edilmiştir. Görüşmelerde öğrencilere etkinlik süreci, geliştirdikleri elektronik ürün ve kademelendirme süreci hakkında sorular sorulmuştur. Grup sözcüleri ile yapılan görüşmeler ortalama 20 dakika sürmüştür ve ses kayıt cihazı ile kayıt altına alınmıştır.

\subsubsection{Elektronik Ürün Değerlendirme Formları (Rubrik)}

Çalışmada, kademelendirilmiş etkinlik temelli eylem planı sonunda öğrencilerden bir ürün (yazılım) ortaya koymaları istenmiştir. Bu bağlamda öğrencilerin Bilgisayar Bilimi dersindeki güz dönemi akademik başarıları ve araştırmacılar tarafından kademelendirmede yardımcısı olması amacıyla geliştirilen öz değerlendirme formu yanıtlarına göre üç farklı kademe oluşturulmuştur. Her kademedeki öğrenci ürünleri farklılık gösterdiğinden, her kademe (başlangıç, orta ve ileri) için ayrı ürün değerlendirme formu (rubrik) hazırlama yoluna gidilmiştir. Değerlendirme formları holistik puanlamaya uygun olarak hazırlanmıştır. Kan'a (2007) göre holistik puanlama değerlendirme genel olarak yapıldığında, işin sonucuna göre 
puan verilmek istendiğinde kullanılabilmektedir. Ürün değerlendirme formu maddeleri araştırmacılar tarafından ürün geliştirme süreci dikkate alınarak oluşturulmuştur. Ayrıca form iki lise Bilgisayar Bilimi dersi öğretmenine sunularak maddeler hakkında görüşleri alınmış ve düzeltmeler yapılmıştır.

\subsection{6 Öğrenci Günlükleri}

Eylem planının uygulama sürecinde öğrencilerden yaşadıkları süreci ve deneyimlerini not almaları (günlük tutmaları) istenmiştir. Bunun için e-öğrenme ortamı sunan Edmodo (www.edmodo.com) kullanılmıștır. Öğrenciler her ders sonunda Edmodo'ya giriş yaparak, hem ürünün o sürece kadar geliştirdikleri halini hem de yansıtıcı günlüklerini (reflective diary) paylaşmışlardır.

\subsection{Eylem Planı Uygulama Süreci}

$\mathrm{Bu}$ araştırmanın bir devlet lisesinde Bilgisayar Bilimi dersi öğretmeni olan ilk yazarı programlama öğretimi konusunda yaşadığı zorlukların üstesinden gelmek için öğrenme ortamında değişiklik yapma ihtiyacı hissetmiştir. Üniversite-okul ortaklığına dayanan işbirlikli eylem araştırması yapmak üzere birlikte yola çıkan araştırmacılar, bu çalışmanın odağını oluşturan sorunu tanımlayabilmek adına sürece öğrencilere $(n=110)$ yazılı olarak birkaç soru sorarak başlamıştır. Bu sorular; a) Bu derste en çok karşılaştığınız sorun nedir? Bir örnekle anlatınız., b) Ne olsaydı bu dersi daha çok severdiniz? Bir örnekle açıklar mısınız? şeklindedir. Öğrencilerden gelen yanıtlar incelendiğinde, karşılaşılan sorunların kodlamada zorlanma $(f=67)$, donanım yetersizliği/bilgisayar sayısı $(\mathrm{f}=20)$, kitap eksikliği $(\mathrm{f}=6)$, öğretmenin her öğrenciye zaman ayıramaması $(\mathrm{f}=6)$, sinav kaygısı $(\mathrm{f}=4)$, dersin sikıc1lığ1 $(\mathrm{f}=4)$, oyun oynayamama $(\mathrm{f}=3)$ olduğu görülmüştür. Öğrenciler eğlenceli etkinlikler $(\mathrm{f}=27)$, oyun oynama $(\mathrm{f}=26)$, oyun kodlama $(f=9)$, donanım eksiklerinin giderilmesi $(f=12)$, code.org sitesinin kullanılmasi $(f=6)$, robot programlama ( $\mathrm{f}=3$ ), proje üzerinde çalışma $(\mathrm{f}=3)$, üç boyutlu tasarım $(\mathrm{f}=2)$ ve uygulama yazma $(\mathrm{f}=3)$ gibi yollarla bu dersi daha çok seveceklerini belirtmişlerdir. Daha sonra öğrencilerin yazılı olarak ilettikleri görüşlerde öne çıkan "eğlenceli etkinlik" ve "eğlenceli ders" hakkında ne kastettiklerini öğrenmek için gönüllü dokuz öğrenciyle informal görüşmeler yapılmıştır. Öğrenciler görüşmelerde derse katılımlarını sağlayan, dersi anlamalarını kolaylaştıracak eğlenceli bir ders ortamı beklediklerini belirtmişlerdir. Ayrıca yazmak istedikleri kodlara ve çalışmak istedikleri arkadaşlara kendileri karar vermek istediklerini iletmişlerdir.

Öğrencilerden gelen bu görüşlerden yola çıkarak alanyazın taraması gerçekleştirilmiş, programlama öğretimine ilişkin araştırmaların (Alsancak Sırakaya, 2019; Elçiçek, 2019; Yıldız Durak, Karaoğlan Yılmaz \& Yılmaz, 2018) daha çok yükseköğretim ve ortaokul düzeyinde gerçekleştiği görülmüştür. Lise düzeyindeki araştırmalar ise bilgi işlemsel düşünme becerisi, akı1 yürütme ve problem çözme becerileri arasındaki ilişkilere (Barut, Tuğtekin \& Kuzu, 2016; Demirer \& Sak, 2016; Korkmaz, Karaçaltı \& Çakır, 2018; Roman-Gonzalez, Perez-Gonzalez \& Jimeenez-Fernandez, 2016; Weintrop vd., 2016) ve görsel ya da metin tabanl1 programlamanın öğrencilerin ilgi ve akademik başarılarına etkilerine (Al-Bow vd., 2009; Gezgin, Özcan, Ergün, Köse \& Emir, 2017; Numanoğlu \& Keser, 2017; Weintrop \& Wilensky, 2017) odaklanmaktadır.

Daha sonra öğrencilerin birinci dönem Bilgisayar Bilimi ders başarıları, demografik özellikleri ve diğer derslerdeki akademik durumları gözden geçirilmiş, sınıfın oldukça farklı öğrenme özellik ve gereksinimlere sahip öğrencilerden oluştuğu sonucuna ulaşılmıştır. Böylece araştırmacılar "proje tabanlı öğrenme", "problem tabanlı öğrenme", "durum tabanlı öğrenme" seçenekleri ile "farklılaştırılmış öğretim" yaklaşımlarını inceleyip tartışmışlardır. Sınıftaki 
öğrencilerin farklı özellik, gereksinim ve hazırbulunuşluk düzeylerinde olmalarını temele alarak farklılaştırılmış öğretim tekniklerinden kademelendirilmiş etkinliği temele alan bir eylem planı araştırmacılar tarafından geliştirilmiştir.

İki aydan bir öğretim yılına kadar uzayabilen eylem araştırmaları örneklerinde olduğu gibi (Johnson, 2014: 21), bu araştırmada eylem planı sekiz hafta olarak planlanmıștır. Her bir öğrenci, öz değerlendirme formu ve birinci dönem Bilgisayar Bilimi dersi akademik başarıları incelenerek -kademelendirilmiş öğretim tekniğine göre- beyaz (başlangıç), mavi (orta düzey) ve kırmızı (ileri düzey) olmak üzere gruplara atanmıştır. Her bir düzeye uygun yazılım sözleşmesi etkinliği hazırlanarak öğrencilerin etkinliklere güdülenmeleri sağlanmaya çalışılmıştır. Yazılım geliştirme sözleşmesinde; öğrencilerden bir sanal şirket oluşturmaları ve bu sanal şirkete bir isim ve logo bulmaları beklenmektedir. Sözleşmede sanal bir müşteri tanımlanmış ve bu müşterinin ihtiyacı olan yazılıma ilişkin özellikler belirtilmiştir. Öğrencilerden beklenen yazılım, en çok ilgi duydukları alanlara göre başkalarına öneriler sunabilecekleri şekilde kurgulanmıştır. $\mathrm{Bu}$ ilgi alanları spor, seyahat, yemek, moda vb. gibi yazılım geliştirme sözleşmesinde belirtilenlerden ya da grupların kendi belirledikleri alanlardan seçilebilmiştir. Geliştirilen yazılımın, girilen kişisel bilgileri temele alarak seçilen ilgi alanına (örneğin spor, seyahat, oyun, moda, yemek, müzik vb.) göre öneriler sunması beklenmektedir. Sözleșme ile öğrencilerden ayrıca grup sözcüsü belirlemeleri ve sözleşmeyi imzalamaları istenmektedir. Eylem planına göre veri toplama araçları Tablo 1'de yer almaktadır:

Tablo 1. Eylem Planına Göre Veri Toplama Araçları

\begin{tabular}{|c|c|c|}
\hline Hafta & Etkinlik & Veri Toplama Araçları \\
\hline 1 & $\begin{array}{l}\text { Öğrencilerin gruplara atanması } \\
\text { Gruplar tarafından yazılım sözleşmesinin } \\
\text { imzalanması }\end{array}$ & $\begin{array}{l}\text { Programlamaya Yönelik Tutumunun } \\
\text { Belirlenmesi Ölçeği } \\
\text { Akademik Güdülenme Ölçeği } \\
\text { Öz değerlendirme Formu }\end{array}$ \\
\hline 2 & $\begin{array}{l}\text { Kademelere öğrenci seçimi } \\
\text { Yazılım geliştirme yönergesinin dağıtılması } \\
\text { Grup sözcüsü seçimi }\end{array}$ & $\begin{array}{l}\text { Öğrenci günlükleri } \\
\text { Öğretmen alan notları }\end{array}$ \\
\hline 3-7 & $\begin{array}{l}\text { Öğrencilerin yönergede belirtilen görevleri } \\
\text { yerine getirmesi ve grupların izlenmesi }\end{array}$ & $\begin{array}{l}\text { Öğrenci günlükleri } \\
\text { Öğretmen alan notları } \\
\text { Ders video kayıtları }\end{array}$ \\
\hline 8 & $\begin{array}{l}\text { Öğrenci ürünlerinin değerlendirilmesi } \\
\text { Konuk ziyareti (Yazılım Geliştirme } \\
\text { Uzmanı) }\end{array}$ & $\begin{array}{l}\text { Elektronik Ürün Değerlendirme Formu } \\
\text { Programlamaya Yönelik Tutumunun } \\
\text { Belirlenmesi Ölçeği } \\
\text { Akademik Güdülenme Ölçeği } \\
\text { Öğrencilerle yüz yüze görüşmeler }\end{array}$ \\
\hline
\end{tabular}

Eylem planının ikinci haftasında ögrencilere aynı renk (kademe) gruplarından olmak üzere grup arkadaşlarını seçmeleri için zaman tanınmış, böylece dört beyaz, dört mavi ve iki kırmızı grup oluşmuştur. Üç ila yedinci haftalar arasında, öğrencilerden yönergelerinde yer alan ve grup arkadaşlarıyla birlikte oluşturmaları beklenen ürünün oluşmasına yardımcı olacak; algoritma ve akış şeması oluşturma, veri girişi, öneri oluşturma, önerileri listeleyebilme ve saklayabilme gibi farklı sayıda görevi (beyaz gruplar için üç, mavi gruplar için dört ve kırmızı gruplar için beş görev) gerçekleştirmeleri istenmiştir. Eylem planının son haftasında ise öğrencilerden hazırladıkları yazılımları sunmaları istenmiştir. Ortaya çıkan yazılımlar (ürünler), araştırmacılar tarafından oluşturulan "Elektronik Ürün Değerlendirme Formu" kullanılarak, ilk yazar da dahil olmak üzere farklı Anadolu liselerinde görev yapan üç Bilgisayar Bilimi dersi öğretmeni tarafından bağımsız bir şekilde puanlanmıştır. Dersin son yirmi dakikasında da sınıfa, günlük hayatta mesleği yazılım geliştirmek olan bir kişi davet edilmiştir. Bu süreçte öğrenciler sınıfta 
Kademelendirilmiş Etkinlik Yoluyla Metin Tabanlı Programlama Öğretimi: İşbirlikli Bir Eylem Araştırması

yaşadıkları deneyimlerini aktarmışlar, uzman ise günlük hayatta bu deneyimlerin yansımalarının nasıl olduğuna dair görüşlerini paylaşmıştır.

Öğrencilerden eylem planı sürecinde her hafta günlük yazmaları istenmiştir. Ayrıca eylem planı sonrasında ÖPYTBÖ ve AGÖ sontest olarak uygulanmıştır. Süreç sonunda her grubun sözcüsüyle de yarı yapılandırılmış görüşmeler $(\mathrm{n}=10)$ yapılmıştır.

Eylem planının uygulanması sonrasında elde edilen nicel ve nitel veriler analiz edildiğinde, Kademelendirilmiş Etkinlik temelli eylem planının metin tabanlı programlama öğretimine katkı getirdiği görüldüğünden ikinci bir eylem planına gerek duyulmamıştır. Süreçte veri toplamak üzere ÖPYTBÖ, AGÖ, ders video kayıtları, görüşmeler, elektronik ürün değerlendirmeleri ve öğrenci günlükleri kullanıldığından, çoklu veri seti elde edilebilmiştir. Veri çeşitlemesi sayesinde eylem planının işlerliği hakkında derinlemesine bilgi alınabilmiş, uygulamada herhangi bir sıkıntı yaşanmamış ve değişikliğe ihtiyaç duyulmamıştır. Gordon ve Solis (2018) de, işbirlikli eylem araştırmalarıyla ilgili verdiği örneklerde veri çeşitlemesi sayesinde tek bir eylem planının işe yaradığını belirtmektedir.

\subsection{Verilerin Analizi}

Çalışmada nitel ve nicel veriler ayrı ayrı analiz edilmiş ve sonuçlar birlikte yorumlanmıştır. ÖPYTBÖ'den elde edilen puanlar üzerinde ilişkili örneklemlerde t-testi (paired samples t-test) ve holistik olarak değerlendirilen (rubrik) öğrenci ürünlerinden elde edilen puanlar üzerinde ise ilişkisiz örneklemler için tek yönlü varyans analizi (One-way ANOVA) gerçekleştirilmiştir. Normal dağılım elde edilemediğinden, AGÖ puanları üzerinde de Wilcoxon işaretli sıralar testi uygulanmıştır.

Nitel verilerin analizinde ise içerik analizi kullanılmıştır. Araştırmada elde edilen video kayıtları her kayıt sonrasında tekrar izlenmiş, öğrenciler tarafindan her hafta yapılan dersin sonunda yazılan günlükler gün sonunda okunmuş, hatırlamak amaciyla alınan alan notları tekrar gözden geçirilmiştir. Bu nedenle veri analizine eylem planı süreci boyunca devam edilmiştir. Maxwell (2018: 104) ilk görüşme ya da gözlemden sonra verilerin analizine hemen geçilmesinin ve araştırma süresince analize devam edilmesinin uygun olacağını belirtmektedir. Gerçekleştirilen eylem planı sonrasında da günlük, kamera kaydı ve görüşme kayıtlarından elde edilen veriler birkaç kez gözden geçirilmiş, veriler arasındaki ilişkiler kısaca not alınmıştır. Creswell (2017: 153) nitel verilerin analizinde kodlamaya başlanmadan önce eldeki verileri tekrar gözden geçirdiğini, böylece veri tabanı hakkında genel bir anlayışa sahip olduğunu belirtmektedir. Sonraki aşamada metin haline getirilen veriler, birinci araştırmacı tarafindan satır satır okunmuş ve bir hesap tablosu programı aracılığıyla kodlanarak not alınmıştır. Elde edilen ilk kodlar, kodlama işlemi esnasında geçici temalara dönüştürülmüştür. Oluşan temalar incelenmiş, birbiriyle kesişen temalar yeniden düzenlenmiştir. Araştırmada ortaya çıkan dört temaya (ders algısındaki değişim, kademelendirme süreci, başarı kaynakları hakkında görüşler ve grupla çalışma süreci) aynı yol izlenerek ulaşılmıştır. İçerik analizi sürecini açıklamak adına Tablo 2'de "Ders Algısında Değişim" temasını oluşturan görüşlerden bazıları örnek olarak verilmiştir:

Tablo 2. "Ders Algısındaki Değişim” Temasını Oluşturan Kod ve Alıntı Örnekleri

\begin{tabular}{lll}
\hline \multicolumn{1}{c}{ Tema } & \multicolumn{1}{c}{ Kodlar } & \multicolumn{1}{c}{ Alıntılar } \\
\hline \multirow{2}{*}{$\begin{array}{l}\text { Ders } \\
\text { Algısındaki }\end{array}$} & Anlamama & $\begin{array}{l}\text { En başında biz gerçekten hiçbir şey anlamıorduk. } \\
\text { Uygulamadan önce çok boştu benim için ve diğerleri için. }\end{array}$ \\
\cline { 2 - 3 } Deģim & İşe yarama & $\begin{array}{l}\text { Bu soruları (ders hakkındaki görüşlerimizi) sormanız işe } \\
\text { yaradı bence. (Öğrenci 1) }\end{array}$ \\
\hline
\end{tabular}


Tablo 2. (devami)

\begin{tabular}{lll}
\hline Tema & \multicolumn{1}{c}{ Kodlar } & \multicolumn{1}{c}{ Alıntılar } \\
\hline \multirow{2}{*}{ Önyargı } & $\begin{array}{l}\text { Bu okula ilk başladığında bilgisayar dersinde ne görüyoruz ki } \\
\text { diyordum bu bastaydı sonuçta. Ama şu anda şey } \\
\text { diyebiliyorum. (Öğrenci 2) }\end{array}$ \\
\cline { 2 - 3 } & Değerli görme & $\begin{array}{l}\text { İyi ki de şunu görmüşüm, iyi ki de bu dersimiz var } \\
\text { diyebiliyorum. (Öğrenci 2) }\end{array}$ \\
\cline { 2 - 3 } Dersi sevmek & $\begin{array}{l}\text { Herkesin ilgi alanına göre olması daha çok sevmemi sağladı } \\
\text { mı? Evet. Ben zaten seviyordum. (Öğrenci 3) } \\
\text { Peğişimin olmaması }\end{array}$ \\
Yine aynı seviyorum yani. (Öğrenci 3)
\end{tabular}

\subsection{Geçerlik ve Güvenirlik}

İlk yazarın uzun zamandır öğrencilerle bir arada olması nedeniyle doğal ders akışı içerisinde eylemleri gerçekleştirmesi, nitel ve nicel veri toplama araçlarının birlikte kullanılması, araştırmacıların önyargılarını açı bir şekilde ifade etmeleri geçerliği sağlamak adına alınmış önlemlerdir. Bunun yanında öğrenci görüşlerinin ses kayıt cihazıyla kayıt altına alınarak sonrasında transkript edilmesi, araştırmacıların rollerinin tanımlanması, kademelendirilmiş etkinliğe ilişkin kuramsal çerçeveden kast edilenin ne olduğunun belirtilmesi, veri toplama ve analiz işlemlerinin ayrıntılı olarak araştırmada yer alması da güvenirlik için alınan önlemlerdir.

\subsection{Araștırmacıların Rolü}

İşbirlikli eylem araştırmalarının eğitimdeki değişim için modern bir katalizör olduğuna katıldığımızdan (Schmuck, 2008), eğitimcilerin işbirliği içinde yeni denemelere girişmeleri, bu girişimleri değerlendirmeleri ve düzeltmeler yoluyla yeniden başlamalarına imkân sağlayan eylem araştırmalarının kuramla uygulama arasında bir köprü kurduğunu düşünüyoruz. Meslekte $11 \mathrm{y} 1 \mathrm{l}$, lise düzeyinde programlama eğitiminde beş yıllık deneyimi olan ilk yazarın eylem planının gerçekleştirildiği dersi yürütmesi, yazılım sözleşmesi etkinliği gereğince kademelendirilen grupların oluşturulmasını kolaylaştırmıştır. Bunun yanında sınıfın yapılan araştırmayı dersin doğal akışı içerisinde görmesine neden olmuş ve bu durum araştırmanın geçerliğine olumlu olarak yansımıştır. Öte yandan düzeylerin (başlangıç, orta ve ileri) belirlenmesinde ÖPYTBÖ, AGÖ, öz değerlendirme formu ve birinci dönem Bilgisayar Bilimi dersi notları kullanılmasına ve süreçte objektif olmaya özen gösterilmesine rağmen, ilk yazarın/öğretmenin öğrencileri daha önceden tanıması kademelendirilen gruplara karşı ön yargılarını da beraberinde getirmiş, alan notlarını alırken bu önyargı ile hareket etmiş olması ihtimalini doğurmuştur. $\mathrm{Bu}$ noktada ikinci yazar, verilerin analizine ve yorumlanmasına dışarıdan bir bakış açısı getirmiş ve birlikte çözümler aranmıştır. Böylece veri analizinde alan notları işe koşulurken, video kayıtlarıyla da desteklenebilen verilerin kodlamada kullanılmasına özen gösterilmiştir. Başka bir deyişle, video kayıtlarıyla desteklenmeyen alan notları kullanılmamıştır.

\subsection{Etik Kurul İzin}

Bu çalışma için etik kurul izni Ege Üniversitesi Rektörlüğü Sosyal ve Beşeri Bilimler Bilimsel Araştırma ve Yayın Etiği Kurulu'nun 12/06/2020 tarihli ve 138358 numaralı kararı ile alınmıştır.

\section{Bulgular}

\subsection{Nicel Bulgular}


Kademelendirilmiş Etkinlik Yoluyla Metin Tabanlı Programlama Öğretimi: İşbirlikli Bir Eylem Araştırması

\subsection{1. Öğrencilerin Programlamaya Yönelik Tutumlarındaki Değişim}

Verilerin analizi basıklık değerinin \pm 1 aralığında olduğunu göstermektedir (kurtosis $=-0.397$ ). George ve Mallery (2010), \pm 1 basıklık değerlerinin normal dağılım için mükemmel aralık olduğunu belirtmektedirler. Öğrencilerin programlamaya yönelik tutumlarındaki değişimi gösteren $\mathrm{t}$ testi sonuçları Tablo 3 'te yer almaktadır:

Tablo 3. Öğrencilerin ÖPYTBÖ Öntest (1) ve Sontest (2) Puanlarının t-testi Sonuçları

\begin{tabular}{lcccccc}
\hline Ölçüm (ÖPYTBÖ) & N & $\overline{\mathbf{X}}$ & SS & sd & $\mathbf{t}$ & $\mathbf{p}$ \\
\hline Öntest & 30 & 31.80 & 12.42 & 29 & -3.102 & .01 \\
Sontest & 30 & 38.13 & 12.42 & & & \\
\hline
\end{tabular}

T-testi sonucunda öğrencilerin ÖPYTBÖ öntest ve sontest puanları arasında anlamlı bir fark bulunmuştur $\left[\mathrm{t}_{(29)}=-3.102, \mathrm{p}<.01\right]$. Tablo 3 'te görüldüğü gibi öğrencilerin sontest ortalamalar1 $(\overline{\mathrm{X}}=38.13)$, öntest ortalamalarına $(\overline{\mathrm{X}}=31.80)$ göre daha yüksektir. Bu bulgu gerçekleştirilen eylem planının programlamaya yönelik tutumda olumlu bir değişiklik oluşturabildiğini göstermektedir.

\subsubsection{Kademelendirilmiş Grupların Hazırladığı Elektronik Ürünlerin Karşılaş̧ırılması}

Dağılımın normalliğini incelemek üzere yapılan analizlerde basıklık (kurtosis) değeri \pm 2 aralığında bulunmuştur (kurtosis $=-1.565$ ). George ve Mallery (2010), \pm 2 basıklık değerlerinin normal dağılım için kabul edilebilir olduğunu belirtmektedir. Gerçekleştirilen eylem planı sonrası tasarlanan elektronik ürünlerin değerlendirme formları (rubrik) aracılığıyla aldıkları puanların ortalamaları (toplam puanların 100 üzerinden karşılıkları) ve standart sapmaları Tablo 4 'te sunulmuştur:

Tablo 4. Farklı Düzeydeki Grupların Elektronik Ürün Değerlendirme Formlarından Aldıkları Puan Ortalamaları

\begin{tabular}{lccc}
\hline \multicolumn{1}{c}{ Grup/Düzey } & N & $\overline{\mathbf{X}}$ & SS \\
\hline Beyaz (başlangıç) & 13 & 64.77 & 13.12 \\
Mavi (orta) & 12 & 58.16 & 17.97 \\
Kırmızı (ileri) & 5 & 81.00 & 3.65 \\
\hline
\end{tabular}

Farklı düzeydeki grupların elektronik ürün değerlendirme formlarından aldıkları puan ortalamaları incelendiğinde kırmızı grupta yer alan öğrencilerin en yüksek ( $\bar{X}=81.00)$, mavi grupta yer alan öğrencilerin ise en düşük $(\overline{\mathrm{X}}=58.16)$ puan ortalamasına sahip oldukları görülmektedir.

Kademelendirilmiş grupların elektronik ürün değerlendirme formlarından aldıkları puanlara göre ANOVA sonuçları Tablo 5'te yer almaktadır:

Tablo 5. Kademelendirilmiş Grupların Elektronik Ürün Değerlendirme Formlarından Aldıkları Puanlara Göre ANOVA Sonuçları

\begin{tabular}{lcccccc}
\hline $\begin{array}{c}\text { Varyansın } \\
\text { Kaynağı }\end{array}$ & $\begin{array}{c}\text { Kareler } \\
\text { Toplamı }\end{array}$ & Sd & $\begin{array}{c}\text { Kareler } \\
\text { Ortalaması }\end{array}$ & F & p & $\begin{array}{c}\text { Anlamlı } \\
\text { Fark }\end{array}$ \\
\hline Gruplar arası & 1840.404 & 2 & 920.202 & 4.380 & $.023 *$ & $2-3$ \\
Gruplar içi & 5672.057 & 27 & 210.076 & & & \\
Toplam & 7512.460 & 29 & & & & \\
\hline *p $<.05$ & & & & &
\end{tabular}


Yapılan varyans analizi sonuçları öğrencilerin yer aldığı kademelere göre anlamlı farklılık göstermektedir $\left[\mathrm{F}_{(2,27)}=4.380, \mathrm{p}<.05\right]$. Anlamlı farkın hangi gruplar arasında olduğunu tespit etmek amacıyla yapılan Tukey HSD çoklu karşılaştırma testi sonuçlarına göre ise anlamlı farkın orta ve ileri düzey kademelerinde yer alan puanlar arasında olduğu görülmüştür.

\subsection{3. Öğrencilerin Akademik Güdülenme Düzeylerindeki Değişim}

Öğrencilerin AGÖ ölçeğinden aldıkları puanlar incelendiğinde verilerin parametrik istatistikler için normallik varsayımını karşılayamadığı görülmüştür. Bu nedenle veriler üzerinde Wilcoxon işaretli sıralar testi uygulanmıştır. Büyüköztürk'e (2011: 162) göre bu test ilişkili iki ölçüm setine ait puanlar arasındaki farkın anlamlılı̆ıını test etmek amacıyla kullanılır ve en güçlü parametrik olmayan testler arasında yer almaktadır. Öğrencilerin eylem planı öncesi ve sonrası güdülenme düzeylerinde anlamlı bir farklılık gösterip göstermediğine ilişkin Wilcoxon işaretli sıralar testi sonuçları Tablo 6'da verilmiştir:

Tablo 6. Akademik Güdülenme Ölçeği Öntest-Sontest Puanlarının Wilcoxon İşaretli Sıralar Testi Sonuçları

\begin{tabular}{lccccc}
\hline \multicolumn{1}{c}{ Sontest-Öntest } & n & Sıra Ortalaması & Sıra Toplamı & z & p \\
\hline Negatif Sira & 18 & 15.17 & 273.00 & $-0.834^{*}$ & .404 \\
Pozitif Sıra & 12 & 16.00 & 192.00 & & \\
Esit & 0 & & & & \\
\hline
\end{tabular}

*Pozitif sıralar temeline dayalı

Wilcoxon işaretli sıralar testi sonuçları öğrencilerin AGÖ ölçeğinden aldıkları öntest-sontest puanları arasında anlamlı farkın olmadığını göstermiştir $(\mathrm{z}=-.834, \mathrm{p}>.05)$. Bu sonuçlara göre elde edilen nicel veriler gerçekleştirilen eylem planının öğrencilerin akademik güdülenme düzeylerine etkisinin olmadığını göstermektedir.

\subsection{Nitel Bulgular}

Öğrencilerle yapılan görüşmeler $(n=10)$ ve öğrenciler tarafindan her hafta elektronik ortama yazılması istenen günlüklerin analizi sonucunda; ders algısındaki değişim, kademelendirme süreci (ilgi, motivasyon, program yazma becerileri), başarı kaynakları hakkında düşünceler ve grupla çalışma süreci olmak üzere dört temaya ulaşılmıştır. Elde edilen temalar dikkate alınarak bulgular aşağıda sunulmuştur.

\subsubsection{Ders Algısındaki Değişim}

Eylem planı öncesinde öğrenciler Bilgisayar Bilimi dersini anlamakta zorlanma, seçmeli bir ders olması nedeniyle onu önemsememe, yazılıma karşı ilgisiz olma ve başarısızlık korkusu gibi gerekçelerle dersi sıkıcı bulduklarını, oyun oynamak istediklerini belirtmişlerdir. Ayrıca öğrenciler dersi kitap odaklı bulmuşlar ve derse ilişkin kendi görüşlerinin alınmamasının derse karşı olumsuz tepkiler geliştirmelerine neden olduğunu ifade etmişlerdir. Eylem planı sonrasında ise verilen görevlere dair sorumluluk hissettiklerini, dersin daha eğlenceli ve akıcı geçtiğini belirtmişlerdir. Öğrenciler ders algılarındaki değişimi; etkinliği kendi ilgi alanlarına göre uyarlayabilme, ders sürecine ait görüşlerinin alınması, kodlamanın devreye girmesi, etkinlik sürecinde bir role girmeleri ve grup çalışmalarına dayandırmaktadırlar. Aşağıda bazı doğrudan alıntılar ve günlük notları yer almaktadır:

"Daha çok derse olan ilgimi artırd, kodlama konusunu daha çok sevmeye başladım... Normalde ben teneffüslerde bilgisayar başında durmazdım. Teneffüslerde de bilgisayarla uğraşmaya başladım kodlama ile ilgili..." (Görüşme, Öğrenci 10) 
Kademelendirilmiş Etkinlik Yoluyla Metin Tabanlı Programlama Öğretimi: İşbirlikli Bir Eylem Araştırması

"Bugün daha önceki haftalarda oluşturmuş olduğumuz akışşeması ve algoritmaya göre kod yazmaya başladık. Henüz bitmedi fakat sandiğımdan daha hızlı ve daha hırsliyız ve çok eğleniyoruz." (Yansitıcı Günlük, Grup Esperanto, 15 Mayıs 2019)

\subsubsection{Kademelendirme Süreci (İlgi, Motivasyon ve Program Yazma Becerileri)}

Öğrencilerin görüşleri ve yansitıcı öğrenci günlükleri incelendiğinde; kademelendirme sürecine ilişkin "ilgi", "motivasyon" ve "program yazma" becerisi olmak üzere üç alt tema ortaya çıkmıştır. Öğrenciler kademelendirmeyi genel olarak olumlu bulmuşlar, fakat kademelendirmeyi sorgulayan ve öneri getiren öğrencilere de rastlanmıştır. Kendi seçtikleri ilgi alanlarına (spor, seyahat, yemek, moda, makyaj, oyun, müzik ya da diğer) uygun bir senaryo içerisinde program yazmanın dersteki en önemli farklılık olduğu ve bunun program yazma becerilerini geliştirdiğine ilişkin görüşler yer almıştır. Bunun yanında, bu uygulamanın derse olan ilgilerinde değişim yaratmadığına ilişkin görüşlere de rastlanmıştır. Öğrenciler kendi seçtikleri ilgi alanlarını grup arkadaşlarıyla birlikte belirlemelerinin ve sevdikleri şeyleri araştırmalarının derse olan katılımlarını olumlu etkilediğini ifade etmişlerdir. Dersin böylece onlara daha eğlenceli geldiğini ve kod yazmayı daha çok sevdiklerini belirtmişlerdir. Aşağıda bazı doğrudan alıntılar ve alan notları yer almaktadır:

"Zaten sporu seçtik ilgi alanımız olduğu için. Onun üzerinden yola çıktık. Bence bizim seçmemiz en önemli şeylerden birisiydi." (Görüşme, Öğrenci 9)

"GBS Write grubunun çalışmasını incelerken listede körling sporunu görünce şaşırdım. Gruptan bir öğrenci "Bu yaşımızda şirket kurduk ona şaşırmıyorsunuz da Körling yazmamıza mı şaşırıyorsunuz” diyerek güldü.” (Alan Notu, 24 Nisan 2019)

Öğrenciler yazılım sözleşmesi etkinliğinde belirtilen görevlerden daha fazlasını yapmak istediklerini fakat zamanlarının yetişmediğini belirtmişlerdir. Program yazmaya ve kademelendirilmiş etkinlikte yer alan görevlerini yerine getirmeye yönelik motivasyonlarındaki artışı birşeyleri yapabildiklerini görmelerine, kendi ilgi alanlarına uygun seçim yapmalarına izin veren kadaemelendirilmiş etkinliğe, grup arkadaşları seçiminin kendilerine bırakılmasına ve sanal bir rolü sahiplenmelerine bağlamışlardır. Öğrencilerin süreçte görüşlerinin alınmasının daha önce derse yönelik korkularını yenmelerine yardımcı olduğunu ve derse motive olarak gelmelerine katkı sağladığını belirtmişlerdir. Ayrıca gerek yansıtma yazıları gerek de kamera kaydı ile desteklenen öğretmen alan notları, öğrencilerin derse motive bir şekilde geldiklerini göstermektedir. Aşağıda bazı doğrudan alıntılar, günlük notları ve alan notları yer almaktadır:

"Sözleşmede belirtilenden fazlasını tabi ki de isterdim ama zaman kısıtlı olduğu için yapamadım. Zaman olsaydı yapabilirdim. Yapabildiğim şeyler bana zevk veriyor çünkü." (Görüşme, Öğrenci 2)

"Bu uygulama (grupla çalışma) bizi birleştirdi ve takım olmamızı sağladı. Bu bizi meraklandirlyor dolaylsıyla bir sonraki haftayı merakla bekliyoruz." (Yansitıcı Günlük, Grup Esperanto, 10 Nisan 2019)

"Teneffüs: Sinıftaki toplam 10 gruptan sekizi sinıftan çıkmamayı tercih ediyor. Teneffüs 10 dakika ve ilk 5 dakika 8 grup, son 5 dakika ise 7 grup çalışmaya devam etmeyi tercih ediyor." (Alan Notu, 8 Mayıs 2019)

Program yazma becerileri açsından öğrenciler kademelendirilmiş etkinlik temelli eylem planı sürecinde yardımsız ya da çok az yardım alarak program (yazılım) geliştirebildiklerini ifade 
etmişlerdir. Program yazma becerilerindeki gelişimin nedeni olarak da gerçekleştirilen kademelendirilmiş etkinliğin kodlamaya dair önyargılarından kurtulmalarına yardımcı olduğunu ve zor bir programlama dili olarak gördükleri Python programlama dilini daha kolay öğrenmelerine katkı sağladığını belirtmişlerdir. Python programla dilinde kendilerini daha rahat hissettiklerini, gerçekleştirilen eylem planı sonrası daha özgüvenli program yazdıklarını ve etkinlik sürecinin getirdiği eğlenceli ders, ilgi alanları ve kademelendirmenin bu başarılarında etkili olduğunu ifade etmişlerdir. Aşağıda bazı doğrudan alıntılar ve alan notları yer almaktadır:

"Bugün çok güzel geçti programımızı çok yardım almadan yaptık ve geliştirdik. Akışşsemasını Python'a geçirdik. Biraz zorlandık ama başardık. Bizim için çok etkili oldu ve çok güzel şeyler başardık. Haftaya daha iyi işler yapacağız.” (Yansıtıcı Günlük, Grup Prestij, 15 Mayıs 2019)

"Dersin ikinci 20 dakikasl: Prestij grubunda "oldu!" diye bir ses duyuluyor. "Hocam bizim program çallşılyor” diyor. Öğrenci heyecanlı görünüyor." (Alan Notu, 15 Mayıs 2019)

\subsubsection{Başarı Kaynakları Hakkındaki Düşünceler}

Eylem planı sürecinde yer alan tüm gruplar görevlerini tamamlamışlardır. Öğrenciler bu başarının altında yatan nedenler olarak gerçekleştirilen etkinliğin kendi düzeylerine uygun olmasını, bu durumun program yazmaya yönelik özgüven kazandırmasını, ilgi alanlarına özgü seçimler yapabilmelerini göstermişlerdir. Aynı zamanda sürecin araştırma becerilerinin gelişimine katkı sağladığını, kendilerini program yazmada yeterli görmeye başladıklarını ve ilerde meslek olarak bu işi tercih edebileceklerini iletmişlerdir. Ayıca süreçte çok çaba sarf ettiklerini fakat yine de dersi eğlenceli bulduklarını ifade etmişlerdir. Aşağıda bazı doğrudan alıntılar yer almaktadır:

"Azim, çalışma ve mutluluk. Bilmiyorum biz bir ara çok heveslendik buna. Çünkü en başında kimsenin hiçbir fikri yoktu ve herkes çok kötümserdi. Yapılmayacak, nasıl yapacağız? Sonra bir şeyler yapa yapa önce akış şeması dedik, yapabiliyoruz yani bir şeyler yapabiliyoruz sonra herkes bir heveslendi onu da yapalım bunu da yapalım falan sonra bitti. Özgüven eksikliği vardı. Başarının sebebi özgüven hocam." (Görüşme, Öğrenci 1)

"En başta bu değişiklik oldu. Grupların değişmesi. Grup çalışmalarına daha çok önem verilmezdi çünkü. Tek başına herkes her şeyi düşünemez ama grup çalışması ile fikir alışverişi yapılarak daha fazla şey ortaya koyması gerektiğini düşünüyorum." (Görüşme, Öğrenci 10)

\subsubsection{Grupla Çalışma Süreci}

Öğrenciler grup çalışmalarını gerçekleştirirken farklı yollar izlemiştir. Örneğin kimi gruplarda görev dağılımı kodlamada iyi olduğu düşünülen ya da baskın olan öğrenci tarafından yapılırken, kimi gruplarda ise karşılıklı konuşularak gerçekleştirilmiştir. Görev paylaşımı sırasında ise grupların büyük bölümü $(\mathrm{n}=7)$ beraber görevi gerçekleştirirken, gruplardan üçü birbirlerinden bağımsız olarak görevlerini yerine getirmeyi tercih etmişlerdir. Öğrenciler genellikle etkinlik süreci boyunca grup arkadaşlarından, diğer gruplardan, ders öğretmeninden ve ders kitabından yardım aldıklarını belirtmektedirler. Kademeleri öğretmenin, grupları ise kendilerinin oluşturmasına olumlu bulmuşlardır. Aşağıda bazı doğrudan alıntılar ve alan notları yer almaktadır:

"Eksiklerimizi kapattık. Onların eksilerini ben, benim eksiklerimi onlar kapattı." (Görüşme, Öğrenci 2) 
Kademelendirilmiş Etkinlik Yoluyla Metin Tabanlı Programlama Öğretimi: İşbirlikli Bir Eylem Araştırması

"Grupta birçok görevi ben yaptım. O yüzden biraz zorlandım açıkçası. Ben de sizden ve arkadaşlarımdan yardım aldım.” (Görüşme, Öğrenci 9)

"Prestij (Başlangıç Düzeyi) grubundan bir ögrenci akışşsemasını kayıt etmek için GBS Write grubuna (Başlangıç Düzeyi) "yardımcı olur musunuz?" diye yardım istiyor. "Seve seve" yanıtını alıyor. GBS Write grubundan bir ögrenci gülümseyerek arkadaşının yanına gidiyor." (Alan Notu, 24 Nisan 2019)

\section{Tartışma ve Sonuçlar}

$\mathrm{Bu}$ araştırmada kademelendirilmiş etkinlik tekniği kullanılarak yürütülen programlama öğretiminin öğrencilerin programlamaya yönelik tutumlarına, güdülenme düzeylerine ve program yazma becerilerine katkı sağladığı görülmüsstür. $\mathrm{Bu}$ sonuçlar, programlama öğretiminde görülen sorunları (Başer, 2013; Bennedsen \& Caspersen, 2019; Erümit vd., 2019; Qian \& Lehman, 2017; Yıldız Durak, 2018) kademelendirilmiş etkinlik tekniğinin çözebileceğini düşündürmektedir.

Ne yazık ki Türkiye'de farklılaştırılmış öğretim tekniklerinden biri olan kademelendirilmiş etkinlikle ilgili olarak çok az sayıda çalışma (Beler \& Avc1, 2011; Demir, 2016) bulunmaktadır. Oysaki öğrencileri belirli hedeflere ulaştırırken ön bilgilerine (Beler \& Avc1, 2011; Saraç, 2017), ilgilerine (Sarı \& Bakır Güven, 2013; Turan \& Demirel, 2010) ve öğrenme stillerine uygun öğretim gerçekleştirmenin (Ergün \& Kurnaz, 2019; Özgen \& Alkan, 2014) akademik başarıyı geliştirdiği bilinmektedir. Beler ve Avcı (2011) ilkokul 3. sınıf Hayat Bilgisi dersinde, Demir (2016) ise ortaokul 5. sınıf Fen ve Teknoloji dersinde kademelendirilmiş etkinlik uygulamasına yer vermişlerdir. Lise düzeyinde ise kademelendirilmiş etkinlik yoluyla yürütülen bir araştırmaya rastlanmadığından, bu çalışmanın ilk örneklerden biri olması önemlidir.

Eylem araştırmasında yer alan 10 grup da yazılım sözleşmesinde belirtilen görevleri tamamlamışlardır. Görevi bütün kademelerdeki (beyaz, mavi ve kırmızı) öğrencilerin tamamlamaları, farklı kademedeki öğrencilere farklı zorluk düzeylerinde görevler sunulmasından kaynaklanmış olabilir. Başlangıç ve ileri seviyedeki grupların hazırladıkları elektronik ürünlerin (yazılımların) orta seviyedeki grupların hazırladıkları elektronik ürünlerden daha yüksek puan aldıkları görülmektedir. $\mathrm{Bu}$ durum gerçekleştirilen kademelendirilmiş etkinliğin farklı hazırbulunuşluk düzeylerine sahip öğrencilerin program yazma becerilerinin gelişimine katkı sağladığını göstermektedir. İlginç bir şekilde, Beler ve Avcı'nın (2011) üçüncü sınıf Hayat Bilgisi dersinde uyguladığı kademelendirilmiş etkinlik araştırmasında da benzer şekilde başlangıç ve ileri seviye gruplarının başarılarında artış belirlenmiştir. Fakat Richards ve Omdal'ın (2007) çalışmasında kademelendirilmiş etkinliğin başlangıç ve orta seviye gruplarında daha fazla etkili olduğu, Demir (2016) ve Suarez'in (2007) çalışmalarında ise bütün seviye gruplarında başarıyı artışı elde edildiği görülmüştür. Bu durumda hangi seviye gruplarında kademelendirilmiş etkinliğin daha fazla katkı getirici olduğuna ilişkin çıkarımlarda bulunabilmek üzere daha fazla araştırmaya ihtiyaç olduğu söylenebilir.

Farklılaştırılmış öğrenme etkinliklerinin öğrencilerin öğrenme sürecine etkin katılım sağlamasına destek olduğuna dair bazı bulgular (Avcı, Yüksel, Soyer \& Balıkçığlu, 2009; Beler, 2010; Karadağ, 2010; Suarez, 2007) bu çalışmadaki bulgularla benzerlik göstermektir. Campbell, Heller ve Pulse (2020) öğrencilerin etkin katılımlarının başarıyı geliştirdiğini, ders memnuniyetini arttırdığını belirtmektedir. Ayrıca Salar (2018), farklılaştırılmış öğretimin olumlu ve destekleyici bir sınıf iklimi oluşturduğunu belirtmektedir. 
Araştırmada yapılan içerik analizi sonucu ortaya çıkan "ders algısındaki değişim" teması, bu önermeleri destekleyen ifadeler içermektedir. Eylem planı sonunda öğrencilerin Bilgisayar Bilimi dersi hakkındaki görüşleri değişmiş, dersi daha akıcı ve eğlenceli bulmuşlardır. Derslerde daha aktif vakit geçirdiklerini belirtmişlerdir. Öğrencilerin kademelendirilmiş etkinlik ile verilen görevi yapabileceklerine olan inançları arttığından teneffüste dahi sınıfta kalarak çalışmayı tercih etmişlerdir. Verilen görevin kendi ilgi alanlarına uygun seçim yapabilme özgürlüğü tanıması ve zorluk düzeyinin farklılaştırılması bunda etkili olmuş olabilir. Bu nedenle programlama öğretimiyle ilgili öğretim programlarının öğrencileri süreçte etkin kılacak ve farklı öğrenci özelliklerini dikkate alacak şekilde yeniden gözden geçirilmesi önerilebilir.

İngiltere'de 5-16 yaşa kadar olan öğretim programlarında bilgisayar bilimin temel kavramları ve bilgi işlemsel düşünme becerisi bütünleşmiş halde yer almaktadır. ABD'de liseler için geliştirilen Bilgisayar Bilimi dersi ile bilgi işlemsel düşünme becerisinin kazandırılması amaçlanmaktadır (Çakır, 2019). Türkiye'de ise liselerde programlama öğretimi ve bilgisayar biliminin temel kavramları, seçmeli Bilgisayar Bilimi dersi öğretim programı ile gerçekleşmektedir. Programlama öğretiminde temel kavramların sağlıklı bir şekilde öğretimi, yazılacak olan programların doğru yapılandırılabilmesine katkı sağlayacaktır (Çelik, 2019). Fakat bu araștırma bulguları göstermektedir ki, doğru kavramlaştırma ve yapılandırmanın yanında öğrencilerin ön bilgilerine ve ilgilerine de dikkat etmek gerekmektedir. Zira öğrencilerin bireysel farklılıklarının öğretimde dikkate alınması program yazma becerilerine katkı getirmektedir. Özellikle gerçekleştirilen kademelendirmeler, öğrencilerin özgüvenleri ve ilgilerine olumlu katkılar yapabilmektedir.

Harackiewicz, Smith ve Priniski’ye (2016) göre ilgi, öğrenme ve akademik başarı anlamında çok önemli bir rol oynamaktadır. Hofstein ve Mamlok-Naaman (2011) öğrencilerin ilgilerini arttırmada üç temel faktör olarak içeriğin, öğretim yönteminin ve cinsiyetin dikkate alınması gerektiğini önermektedir. $\mathrm{Bu}$ araştırmada tercih edilen öğretim yöntemi ve içerik; öğrenci ilgilerini dikkate alacak şekilde düzenlenmiştir. Dolayısıyla uygulanan eylem planında öğrencilerin ilgi alanlarını ve ilgi uyandıran bir bağlamı kullanmanın (yazılım geliştirme sözleşmesinde sanal şirket oluşturma, bu şirkete bir isim ve logo bulma, sanal bir müşteri tanımlama ve bu müşterinin ihtiyacı olan yazılıma ilişkin özellikleri belirtme, yazılımda öğrencilerin en çok ilgi duydukları alanları seçmelerine izin verilmesi vb. etkinlikler) işe yaradığını düşünüyoruz.

Öğrenciler program yazmadaki başarılarının nedenlerinden biri olarak da grup çalışmasını göstermektedirler. Bu durum, farklılaştırılmış öğretimin takım çalışmasını arttırmasına yönelik yararlarını vurgulayan araştırma bulguları ile (Avcı \& Yüksel, 2018; Beler \& Avc1, 2011) benzerlik göstermektedir. Kademelendirilmiş Etkinlikte kademeler öğretmen tarafından belirlenmekle birlikte, grup arkadaşlarının seçimi öğrenciye bırakılmıştır. Bu durum öğrenciler tarafından önemsenmiş ve kendilerini değerli hissetmelerini sağlamış olabilir. Ayrıca öğrenci düzeyine uygun görevler gruplarda görevlerin bir ya da birkaç kişinin üzerine kalmasının önüne geçmektedir. Farklılaştırılmış öğretimle birlikte yürüyen grup çalışmalarının öğrenciler arasında arkadaşlık ilişkilerinde, yardımlaşmada, paylaşım ve iletişim becerilerinde gelişme (Avc1 \& Yüksel, 2018; Beler \& Avc1, 2011; Gregory \& Chapman, 2012; Heacox, 2002; Samms, 2009) ve olumlu sınıf iklimi oluşmasını sağladığı söylenebilir.

Nicel bulgular eylem planının öğrencilerin güdülenmeleri üzerinde istatistiksel olarak anlamlı bir fark yaratmadığını gösterse de, nitel bulgular öğrencilerin güdülenmelerinde olumlu değişikliklere işaret etmektedir. Nicel ve nitel verilerin bir arada kullanıldığı araştırmalarda bazen çelişkili bulgulara rastlanabilmektedir. Esasen veri toplama yöntemlerinde yapılan çeşitleme bulguların geçerliliğini arttırabilir, birbirini tamamlamasına yardımcı olabilir ya da birbiriyle çelişebilir (O'Cathain, Murphy \& Nicholl, 2010). Çelişkili sonuçlar, aynı yöntemi 
kullanan farklı araştırmalar için de geçerli olabilmektedir. Bu durumun bir uyumsuzluktan ziyade, yeni yapılacak araştırmalara yol gösterici olduğu düşünülebilir (Miles \& Huberman, 1994). Aynı zamanda bu tür bulgular çelişki olarak yorumlanmaktan ziyade, çoklu sonuç olarak da düşünülebilir. Bu çalışmada motivasyona ilișkin olarak nitel ve nicel bulgularda ortaya çıkan farklılığın birçok nedeni olabilir. En temelde nicel bulgulara rehberlik eden ölçek maddeleri ile nitel bulgulara rehberlik eden öğrenci görüşleri, alan notları, yansıtma yazıları ve video kayıtlarındaki verilerin, güdülenmelerdeki farklı boyutları çağrıştırmış olabileceği söylenebilir. Örneğin, ölçekte yer alan maddeler daha çok verilen bir görevin yapılmasına odaklanırken, nitel bulgulara yön veren görüşme soruları öğrencilerin kendi seçimlerini yapmaları, yazılımcı rolüne bürünmeleri, karar alma süreçlerine katılım ve başarabileceklerini düşünmeleri gibi noktalara odaklanmaktadır. Dolayısıyla yeni çalışmalarda akademik güdülenmeye ilişkin daha derinlemesine bilgiler elde edilmesi önemli görünmektedir.

Bu çalışma tek bir okul ve sadece 30 öğrenci üzerinde gerçekleştirildiği için bazı sınırlılıklar içermekle birlikte, programlama öğretiminde farklı yaklaşımlara yol gösterici olması bakımından önemli sonuçlar sunmaktadır. Bu bağlamda gelecekte yapılacak çalışmalarda farklılaştırılmış öğretim içerisinde yer alan diğer tekniklerin katkıları incelenebilir, bu tekniklerin blok tabanlı ya da metin tabanlı programlama öğretimindeki etkileri karşılaştırılabilir. Öğretmen ya da öğretmen adaylarına yönelik eğitimler kuram ile uygulamanın eş zamanlı ilerleyeceği bir şekilde; hazırlanan planların tartışılarak uygulandığı ve uygulama sonuçlarının birlikte değerlendirildiği bir biçimde yürütülmelidir. Programlama öğretiminde kademelendirilmiş etkinliğin sınıflarda etkili kullanımı için ise öncelikle hedefin programlama dili öğretiminden ziyade üst düzey düşünme becerileri kazandırmak olduğunun dikkate alınması, öğrencilerin önbilgileri ve ilgi alanlarının öğrenilerek kararlara katılımının mümkün olduğu kadar artırılması, kademelendirme sürecinin dikkatli ve ayrıntılı bir şekilde planlanması ve (özellikle başlangıç seviyesindeki) öğrencilerin özenli bir dille bilgilendirilmesi, gruplar arası iletişim ve dayanışmanın teşvik edilmesi, değerlendirmede birden fazla öğretmenin görev alması ve okul yönetimlerinin bilgilendirilerek sürece destek olması önerilebilir. Sonuç olarak metin tabanlı programlama öğretiminde farklılaştırılmış öğretim tekniklerinin işe yarayabileceği ve bu konuda yapılacak yeni araştırmaların karşılaştırılmasıyla programlama öğretiminde en etkili yolların daha net bir şekilde ortaya çıkabileceği düşünülmektedir.

\section{Kaynaklar}

Adams, P., \& Townsend, D. (2014). From action research to collaborative inquiry: A framework for researchers and practitioners. Education Canada, 54(5), 12-15.

Al-Bow, M., Austin, D., Edgington, J., Fajardo, R., Fishburn, J., Lara, C., \& Meyer, S. (2009). Using game creation for teaching computer programming to high school students and teachers. ACM SIGCSE Bulletin 41(3), 104-108.

Alsancak Sırakaya, D. (2019). Programlama öğretiminin bilgi işlemsel düşünme becerisine etkisi. Türkiye Sosyal Araştırmalar Dergisi, 23(2), 575-590.

Altay, G., \& Kışla, T. (2018). Programlamaya yönelik tutum ölçeği ve psikometrik özellikleri. Ege Eğitim Dergisi, 19(2), 559-574.

Avcı, S., \& Yüksel, A. (2018). Farklılaştırılmış ögretim teori ve uygulama (4. bask1). Ankara: Nobel Yayıncilik.

Avcı, S., Yüksel, A., Soyer, M., \& Balıkçığlu, S. (2009). The cognitive and affective changes caused by the differentiated classroom environment designed for the subject of poetry. Educational Sciences: Theory and Practice, 9(3), 1069-1084. 
Barut, E., Tuğtekin, U., \& Kuzu, A. (2016). Programlama eğitiminin bilgi işlemsel düşünme becerileri bağlamında incelenmesi. 4. Uluslararası Öğretim Teknolojileri ve Öğretmen Ĕ̆itimi Sempozyumu (s. 210-214), Fırat Üniversitesi, Elazı̆̆.

Başer, M. (2013). Attitude, gender and achievement in computer programming. Middle-East Journal of Scientific Research, 14(2), 248-255.

Beler, Y. (2010). Farklılaş̧ırılmış ögretim ortamının sınıf yönetimine ve öğrencilerin akademik başarısına etkisi (Yayımlanmamış yüksek lisans tezi). Maltepe Üniversitesi Sosyal Bilimler Enstitüsü, İstanbul.

Beler, Y., \& Avcı, S. (2011). Öğretimin farklılaştırılmasında etkili bir strateji: Katlı öğretim. Kırşehir Eğitim Fakültesi Dergisi, 12(3), 109-126.

Bennedsen, J., \& Caspersen, M. E. (2019). Failure rates in introductory programming: 12 years later. ACM Inroads, 10(2), 30-36.

Bozanoğlu, İ. (2004). Akademik güdülenme ölçeği: Geliştirmesi, geçerliği, güvenirliği. Ankara Üniversitesi Eğitim Bilimleri Fakültesi Dergisi, 37(2), 83-98.

Büyüköztürk, Ş. (2011). Sosyal bilimler için veri analizi el kitabı (14. baskı). Ankara: Pegem Akademi.

Campbell, L. O., Heller, S., \& Pulse, L. (2020). Student-created video: An active learning approach in online environments, Interactive Learning Environments, 28(1), 806-944. DOI: $10.1080 / 10494820.2020 .1711777$.

Creswell, J. W. (2017). Nitel araştırmacılar için 30 temel beceri. Ankara: Anı Yayıncılık.

Creswell, J. W., \& Plano Clark, V. L. (2018). Designing and conducting mixed methods research (3rd ed.). Los Angeles: Sage.

Çelik, İ. (2019). Programlama ve gelişimi. İçinde Ö. Korkmaz (Ed.) Programlama öğretimi yaklaşımları (s. 3-11). Ankara: Nobel Akademik.

Demir, S. (2016). Katlı öğretim yönteminin öğrencilerin akademik başarı puanları, öğrenme yaklaşımları ve öğrenmenin kalıcılı̆̆ üzerindeki etkisi. Kastamonu Eğitim Dergisi, 24(4), 1589-1602.

Demirer, V. \& Sak, N. (2016). Dünyada ve Türkiye'de programlama eğitimi ve yeni yaklaşımlar. Eğitimde Kuram ve Uygulama, 12(3), 521-546.

Elçiçek, M. (2019). Programlama öğretimine yönelik video destekli çevrimiçi bir öğrenme ortamının tasarımı ve değerlendirilmesi (Yayımlanmamış doktora tezi). Trabzon Üniversitesi Lisansüstü Eğitim Enstitüsü, Trabzon.

Ergün, E., \& Kurnaz, F. B. (2019). E-öğrenme ortamlarında öğrenme stilleri ve akademik başarı arasındaki ilişkinin incelenmesi. Kuramsal Eğitimbilim Dergisi, 12(2), 532-549.

Erümit, K. A., Karal, H., Şahin, G., Aksoy, D. A., Aksoy, A., \& Benzer, A. I. (2019). A model suggested for programming teaching: Programming in seven steps. Education and Science, 44(197), 155-183.

Garcia-Penalvo, F. J., \& Cruz-Benito, J. (2016). Computational thinking in pre-university education. In Proceedings of the Fourth International Conference on Technological Ecosystems for Enhancing Multiculturality, ACM (pp. 13-17). Salamanca, Spain.

George, D., \& Mallery, M. (2010). SPSS for windows step by step: a simple guide and reference (17.0 update). Boston: Pearson. 
Gezgin, D. M., Özcan, S. N., Ergün, K., Köse, Ö., \& Emir, N. (2017). Bilgisayar programlama eğitiminde Scratch programı kullanımına ilişkin lise öğrencilerinin görüşleri. İçinde $\mathrm{H}$. Kaya (Ed.) Proceedings book of 2nd international scientific researches congress on humanities and social sciences (IBAD-2017) (s. 82-188). İstanbul, Türkiye.

Gordon, S. P., \& Solis, R. D. (2018). Teacher leaders of collaborative action research: Challenges and rewards. Inquiry in Education, 10(2), 1-22.

Gregory, G. H., \& Chapman, C. (2012). Differentiated instructional strategies: One size doesn't fit all. USA: Corwin Press.

Harackiewicz, J. M., Smith, J. L., \& Priniski, S. J. (2016). Interest matters: The importance of promoting interest in education. Policy Insights from the Behavioral and Brain Sciences, $3(2), 220-227$.

Heacox, D. (2002). Differentiating instruction in the regular classroom: How to reach and teach all learners. USA: Free Spirit Publishing.

Hofstein, A., \& Mamlok-Naaman, R. (2011). High-school students' attitudes toward and interest in learning chemistry. Educación química, 22(2), 90-102.

Johnson, A. P. (2014). Eylem araştırması el kitabı (Çev. Y. Uzuner ve M. Ö. Anay). Ankara: An1.

Kan, A. (2007). Ödev ve projeler. H. Atılgan (Ed.), Eğitimde ölçme ve değerlendirme içinde (270-294). Ankara: Anı.

Karadağ, R. (2010). İlköğretim Türkçe dersinde farklılaş̧ırılmış öğretim yaklaşımının uygulanması: Bir eylem araştırması (Yayımlanmamış doktora tezi). Anadolu Üniversitesi Eğitim Bilimleri Enstitüsü, Eskişehir.

Korkmaz, Ö., Karaçaltı, C., \& Çakır, R. (2018). Öğrencilerin programlama başarılarının bilgisayarca-eleştirel düşünme ile problem çözme becerileri çerçevesinde incelenmesi. Amasya Üniversitesi Eğitim Fakültesi Dergisi, 7(2), 343-370.

Levy, H. M. (2008). Meeting the needs of all students through differentiated instruction: Helping every child reach and exceed standards. The Clearing House: A Journal of Educational Strategies, Issues and Ideas, 81(4), 161-164.

Maxwell, J. A. (2018). Nitel araştırma tasarımı: Etkileşimli bir yaklaşım (Çev. M. Çevikbaş). Ankara: Nobel.

MEB (2018). Merkezi Sınavla Yerleşen Öğrencilerin Performansı. Eğitim Analiz ve Değerlendirme Raporları Serisi, No: 3, Ankara. 16.06.2019 tarihinde https://www.meb.gov.tr/meb_iys_dosyalar/2018_12/17094056_2018_lgs_rapor.pdf adresinden erişildi.

Miles, M., \& Huberman, A. (1994). Qualitative data analysis: An expanded sourcebook (2nd ed.). Thousand Oaks: Sage Publications.

Numanoğlu, M., \& Keser, H. (2017). Programlama öğretiminde robot kullanımı-mbot örneği. Bartın Üniversitesi Eğitim Fakültesi Dergisi, 6(2), 497-515.

O'Cathain, A., Murphy, E., \& Nicholl, J. (2010). Three techniques for integrating data in mixed methods studies. BMJ, 341, 1147-50.

Özgen, K., \& Alkan, H. (2014). Yapılandırmacı öğrenme yaklaşımı kapsamında, öğrencilerin öğrenme stillerine uygun öğrenme etkinliklerinin akademik başarı ve tutuma etkileri: 
Fonksiyon ve türev kavramı örneklemesi. Türk Bilgisayar ve Matematik Eğitimi Dergisi, $5(1), 1-38$.

Pierce, R. L., \& Adams, C. M. (2004). Tierdless lessons: One way to differentiate mathematics instruction. Gifted Child Today, 27(2), 58-65.

Popat, S., \& Starkey, L. (2019). Learning to code or coding to learn? A systematic review. Computers and Education, 128, 365-376.

Qian, Y., \& Lehman, J. (2017). Students' misconceptions and other difficulties in introductory programming: A literature review. ACM Transactions on Computing Education (TOCE), $18(1), 1-24$.

Richards, M. R., \& Omdal, S. N. (2007). Effects of tiered instruction on academic performance in a secondary science course. Journal of Advanced Academics, 18(3), 424-453.

Roman-Gonzalez, M., Perez-Gonzalez, J. C., \& Fernandez, C. J. (2016). Which cognitive abilities underlie computational thinking? Criterion validity of the computational thinking test. Computers in Human Behavior, 72(1), 678-691.

Sáez-López, J. M., Román-González, M., \& Vázquez-Cano, E. (2016). Visual programming languages integrated across the curriculum in elementary school: A two year case study using "Scratch" in five schools. Computers \& Education, 97, 129-141.

Salar, R. (2018). Fizik eğitiminde farklılaştırılmış ögretim ve $5 E$ ögrenme modelinin farklı değişkenler üzerine etkisi (Yayımlanmamış doktora tezi). Atatürk Üniversitesi, Eğitim Bilimleri Enstitüsü, Erzurum.

Samms, P. (2009). When teachers differentiate reading instruction for fifth grade students: impacts on academic achievement, social and personal development (Unpublished doctoral dissertation). Argosy University, Sarasota.

Saraç, H. (2017). 7E öğretim modeline göre hazırlanan materyallerin öğrencilerin 1sı ve sıcaklık kavramlarını anlamalarına etkisi. Fen Bilimleri Öğretimi Dergisi, 5(1), 1-19.

Sarı, U., \& Bakır Güven, G. (2013). Etkileşimli tahta destekli sorgulamaya dayalı fizik öğretiminin başarı ve motivasyona etkisi ve öğretmen adaylarının öğretime yönelik görüşleri. Necatibey Eğitim Fakültesi Elektronik Fen ve Matematik Eğitimi Dergisi, 7(2), 110-143.

Schmuck, R. (2008). Practical action research: A collection of articles (Ed.). US: Corwin Publishing.

Suarez, D. (2007). Differentiation by challange: Using a tiered program of instruction in mathmatics. In Making the difference: Differentitation in international schools. W. Powel \& O. K. Powel (Eds) (pp. 220-249). CreateSpace Independent Publishing Platform: Kuala Lumpur.

Suprayogi, M. N., Valcke, M., \& Godwin, R. (2017). Teachers and their implementation of differentiated instruction in the classroom. Teaching and Teacher Education, 67, 291301.

Taylor, B. K. (2015). Content, process, and product: Modeling differentiated instruction, Kappa Delta Pi Record, 51(1), 13-17. DOI: 10.1080/00228958.2015.988559

Tomlinson, C. A. (2000). Reconcilable differences: Standards-based teaching and differentiation. Educational Leadership, 58(1), 6-13. 
Kademelendirilmiş Etkinlik Yoluyla Metin Tabanlı Programlama Öğretimi: İşbirlikli Bir Eylem Araştırması

Turan, S., \& Demirel, Ö. (2010). Öz-düzenleyici öğrenme becerilerinin akademik başarı ile ilişkisi: Hacettepe üniversitesi tıp fakültesi örneği. Hacettepe Üniversitesi Eğitim Fakültesi Dergisi, 38(38), 279-291.

van Geel, M., Keuning, T., Frèrejean, J., Dolmans, D., van Merriënboer, J., \& Visscher, A. J. (2019). Capturing the complexity of differentiated instruction. School Effectiveness and School Improvement, 30(1), 51-67.

Weintrop, D., \& Wilensky, U. (2017). Comparing block-based and text-based programming in high school computer science classrooms. ACM Transactions on Computing Education (TOCE), 18(1), 1-25.

Weintrop, D., Beheshti, E., Horn, M., Orton, K., Jona, K., Trouille, L., \& Wilensky, U. (2016). Defining computational thinking for mathematics and science classrooms. Journal of Science Education and Technology, 25(1), 127-147.

Wing, J. M. (2006). Computational thinking. Communications of the ACM, 49(3), 33-35.

Yıldırım, A., \& Şimşek, H. (2013). Sosyal bilimlerde nitel araştırma yöntemleri (9. baskı). Ankara: Seçkin Yayınevi.

Y1ldiz Durak, H. (2018). Digital story design activities used for teaching programming effect on learning of programming concepts, programming self-efficacy, and participation and analysis of student experiences. Journal of Computer Assisted Learning, 34(1), 740-752. DOI: https://doi.org/10.1111/jcal.12281

Yıldız Durak, H., Karaoğlan Yılmaz, F. G., \& Yılmaz, R. (2018). Robot tasarımı etkinliklerinin programlama öğretiminde kullanılmasıyla ilgili ortokul öğrencilerinin görüşlerinin incelenmesi. Ege Eğitim Teknolojileri Dergisi, 2(2), 32-43.

\section{EXTENDED ABSTRACT}

\section{Introduction}

Computational thinking skill was introduced by Wing in 2006, and this basic skill is not only for computer scientists but also for everyone. Although it is thought that students' logical thinking and problem-solving skills will contribute more to computational thinking skills, many countries focus more on programming skills from kindergarten to high schools. In the programming education implemented in high schools, text-based programming and block-based programming applications can be used together. In Turkey, the Computer Science curriculum depending on the basic text-based programming instruction was published in 2018 by the Ministry of Education (MoNE).

Programming is difficult to learn particularly for the students who do not have problem-solving skills and the ability to create effective solution designs. Many factors such as programming syntax knowledge, natural language, mathematics, wrong mental models, lack of strategy, programming environments, teachers' knowledge, and teaching skills have an impact on the difficulties in learning programming. The first researcher, who was a Computer Science course taught at a public high school, also felt the need to make changes in the learning environment to overcome the difficulties, which he also experienced in programming teaching. The researchers developed collaborative action research based on a university-school partnership, and they started the research by asking the students $(n=110)$ some questions in written form to identify the problem, which was the focus of this study. Later, the students' Computer Science course achievements in the fall, demographic features and academic achievement levels in the other 
courses were examined, and it was concluded that the class to be implemented the action plan was composed of the students with very different learning profiles and needs. It is thought that the differentiated instruction, which is based on the fact that students in a classroom have different characteristics, needs and readiness levels, may be suitable for the solutions of the problems experienced during the teaching process as well as for meeting the expectations obtained from the students.

\section{Purpose}

This study examines how an action plan prepared based on the Tiered Instruction from Differentiated Instructional techniques in the elective Computer Science course contributes to students' attitudes, motivation levels and programming skills. The study sought answers to the following questions:

1. How does the text-based programming instructions with the Tiered Activities contribute to students' attitudes towards programming and academic motivation levels?

2. How does the text-based programming instructions with the Tiered Activities contribute to the students' text-based programming skills?

3. What are the students' opinions about the Tiered Activities?

It is thought that the study will contribute to the literature regarding teachers searching for a solution to the problems that students encounter in their first experiences with text-based programming as well as in their learning process.

\section{Method}

Drawing on the collaborative action research, the study was carried out with 30 students at the $9^{\text {th }}$ grade of Anatolian High School in Manisa in the 2018-2019 spring semester. 18 of the students in the class are female and 12 of them are male. Their ages also vary between 14 and 15. The action plan was planned for eight weeks. In the first week, students were asked to fill in the Attitude Scale Towards Computer Programming (ASTCP), Academic Motivation Scale (AMS) and Text-Based Program (Python) Development Self Evaluation Form. In the second week of the action plan, students were given time to choose their group mates from the same color (tier) groups. Accordingly, four white, four blue and two red groups were formed. The "Software Development Agreement Directive" was distributed to the groups. Between the third and seventh weeks of the plan, students were asked to perform a different number of tasks (three tasks for white groups, four for the blue groups, and five for red groups), such as creating an algorithm and flow charts in their guidelines, data entry, creating suggestions, listing and storing suggestions. In the last week, students were asked to present the software they prepared. Data were collected through ASTCP, AMS, course video recordings, interviews, electronic product rubrics and student diaries.

\section{Findings}

Findings show that the implemented action plan can make a positive change in the students' attitudes towards programming, and the electronic products (software) prepared by the beginner and advanced groups scored higher. There is a significant difference between the intermediate and advanced groups' scores from the softwares. Although the action plan does not contribute to the academic motivation levels of the students, the students stated that they wanted to do more than the assigned tasks when they had enough time in the interviews. Also, in the field notes supported by the video recordings, it was seen that many groups preferred to stay in class even 
during recesses to perform their tasks. These results are important in terms of showing that programming instruction through one of the differentiated teaching techniques, tiered instruction, can have positive contributions to high school students.

\section{Discussion and Conclusion}

For the effective use of the tiered instruction in programming teaching, first of all, it is important to consider that the goal is to develop higher-level thinking skills rather than teaching the language of programming, to increase the participation of the students as much as possible by learning their prior knowledge and interests, and to plan the tiered process carefully and in detail (particularly in the beginning level).

The results implied that programming instructions through Tiered Activities from the Differentiated Teaching techniques might have contributions to the students' attitudes towards programming, motivation levels and programming skills. While informing tiered groups, teachers should be careful about their language. Additionally, communication and cooperation should be encouraged among groups. More than one teacher should take part in the assessment process. Also, school administrators should be informed and their supports might be demanded. For further studies, the contributions of other techniques in differentiated instruction can be examined, and the effects of these techniques in block-based or text-based programming teaching can be compared also.

\section{Etik Kurul İzin}

Bu çalışma için etik kurul izni Ege Üniversitesi Rektörlüğü Sosyal ve Beşeri Bilimler Bilimsel Araştırma ve Yayın Etiği Kurulu'nun 12/06/2020 tarihli ve 138358 numaralı kararı ile alınmıştır. 